\title{
Editorial Introduction: Women and Judging
}

\author{
Dermot Feenan
}

Published online: 26 February 2009

(C) Springer Science+Business Media B.V. 2009

Increasing scholarly attention is being paid to women and judging. The literature now covers a wide field, only some of which can be referred to here: ${ }^{1}$ analysis of judicial appointments; the structure, practices and culture of the legal profession (Schultz and Shaw 2003; Resnik 1996); judicial decisions (including both the decisions themselves and their impact, or not, on women, see, e.g. Schneider 2007); whether women judge differently (Malleson 2003); the gendered constitution of law (Graycar 1995); judicial authority (Thornton 1996); and, more recently, the construction of the notion of the judge (Rackley 2002). Empirical, biographical and other narrative studies have revealed important information on women's continuing difficulties, and some successes, in appointment to, and retention in, judicial office. Still, in most parts of the world women continue to be under-represented.

Women's low representation in the judiciary has been reported in a number of regions such as Latin America (Formisano and Moghadam 2005) and the Middle

\footnotetext{
${ }^{1}$ There are a number of special issues on women and judging in the United States: Women in the judiciary (1982) Judicature 65(6); Symposium issue: National Association of Women Judges (1984) Golden Gate University Law Review 14(3); Centennial celebration: A tradition of women in the law (1991) New York University Law Review 66(6); Women on the bench: A different voice? (1993) Judicature 77(3); Workshop on judging: Does gender make a difference? (2001) Wisconsin Women's Law Journal 16; see also Symposium: Women, justice and authority (2002) Yale Journal of Law and Feminism 14(2). A number of journals served as conduits for the reports of taskforces on gender bias in the courts, e.g. Report of the gender bias study of the Supreme Judicial Court (1989) Suffolk University Law Review 23(3); The effects of gender in the federal courts: The final report of the Ninth Circuit Gender Bias Task Force (1994) Southern California Law Review 67. See also Gender and judging (2008) International Journal of the Legal Profession 15(1\&2).
}

D. Feenan (ه)

School of Law, University of Ulster, Newtownabbey BT37 0QB, UK

e-mail: d.feenan@ulster.ac.uk 
East and North Africa, ${ }^{2}$ and in separate jurisdictions. Among common law countries, where admission to judicial office remains largely dependent on performance as an advocate, gender representation remains low. In England and Wales, women make up $16 \%$ of the judiciary, $9 \%$ above the level of High Court. There is only one woman alongside 11 men in the highest court, the House of Lords. Three women sit alongside 34 men as Lord Justices. ${ }^{3}$ In the USA, there is one woman justice alongside eight men on the Supreme Court. In Australia, women comprise $27 \%$ of all judges and magistrates. ${ }^{4}$ Lower representation is found in Ireland (22.4\%) (Feenan 2008a) and, less still (20.9\%) in Northern Ireland (NISRA (Northern Ireland Statistics and Research Agency) 2008). In civil law countries, such as France or The Netherlands, where judicial careers are facilitated at an early stage through judicial qualifications and/or training, women judges' representation is often close to their proportion in the overall population (Bell 2006). And in the mixed jurisdiction of Canada women comprise $39 \%$ of the federal judiciary, and constitute $44.4 \%$ of its highest court, the Supreme Court of Canada. ${ }^{5}$ On regional and international courts, women's representation is generally low. While women comprise $34.7 \%$ of the European Court of Human Rights, they make up $17 \%$ of the European Court of Justice, and there is only one woman alongside 14 men on the International Court of Justice.

The low representation of women in judicial office, among other pressures for change, has led to reform of judicial appointments procedures at various national, regional and international levels (Malleson and Russell 2006) based on a variety of rationales including: fair representation, equality, improved public confidence in the judiciary, diversity, and bringing a different approach to adjudication. Mechanisms for delivering change have varied from constitutional provision for greater gender representation, as in South Africa (Cowan 2006), through softer options such as outreach, to executive intervention to boost women's representation. While in some countries women's representation and status in the judiciary has improved significantly, in other parts of the world, such as Saudi Arabia, women remain excluded from (or severely marginalised within) the judiciary.

The articles within this issue were commissioned from members of the International Research Collaborative on Gender and Judging, sponsored by the Law and Society Association 2006-2007, of which the commissioning editor was Co-Chair. The articles address separately five different countries: the UK, Canada, the USA, Korea, and Australia. The authors deploy a range of approaches:

\footnotetext{
${ }^{2}$ Women, law, and judicial decision-making in the Middle East and North Africa: Toward gender justice. UNESCO Seminar, 11-16 June 2006, Jordan. http://portal.unesco.org/shs/fr/files/10415/11647960621 gender_justice.pdf/gender_justice.pdf. Accessed 12 January 2009. For the position in Syria, see Cardinal (2008).

3 Judiciary of England and Wales, Statistics-Women judges in post: As at 1 April 2008. http://www.judiciary.gov.uk/keyfacts/statistics/women.htm. Accessed 12 January 2009.

4 The Australasian Institute of Judicial Administration. Judges and magistrates (\% of women), updated March 2008. http://www.aija.org.au/index.php?option=com_content\&task=view\&id=32\&Itemid=121. Accessed 12 January 2009.

5 Office of the Commissioner for Federal Judicial Affairs, Number of federal judges on the bench as of 1 January 2009. http://www.fja.gc.ca/fja-cmf/ja-am/n-judges-juges-eng.html. Accessed 12 January 2009.
} 
theoretical, a mix of doctrine and theory, and empirical methodologies. The articles seek to augment existing scholarly work, and also indicate new directions for research on judging. They variously confirm the persistent challenges faced by women considering judicial office, notwithstanding their increased entry at some levels of the judiciary. While postmodernism and queer/critical race/disability theories assist in problematising concepts of gender, the persistent and severe disadvantage faced by women worldwide justifies ongoing use of the category as a meaningful and political concept (Harris 1990). Moreover, as Katharine Bartlett (1990) argued, without asking 'the woman question' assumptions and stereotypes about women often remain unexamined. The effect can reinforce laws and practices that disadvantage women.

Some of the existing literature on women and judging has done much to expose such disadvantage: historical exclusion; quotidian discrimination (including stereotyping); gender-biased appointments procedures and criteria; perceptions of a maledominated, hostile environment (Genn 2008); and working practices that facilitated men's routines rather than women's lives (Brockman 1992, 2001). The 'old boy's network' that hothouses flows of useful information and strengthens the cultural habitus of the male judge has often disadvantaged women (Feenan 2005, 2007). Working practices and residual discrimination continue to exclude women lawyers from progression generally, notwithstanding official commitments to equality and diversity (Thornton and Bagust 2007), and from particular areas of practice traditionally associated with masculine attributes (Thornton 2007). Indeed, Elaine Martin's article in this special issue argues that the experiences of women appointed to the US federal bench by President Carter between 1976 and 1980 still resonate for today's women judges. It is possible, in the current era of economic slowdown and a neo-liberal market economy, that women's opportunities will continue to stall or slip (Epstein 1998; Kay 1997) and require correction.

Much also needs to be done to redress the symbolic exclusion of woman from judging (Berns 1990; Rackley 2002; Thornton 2007; Feenan 2008a) and the problematic gender and racial symbolism of the image of Justicia (Curtis and Resnik 1987; Capers 2006). Where women have made it onto the bench they have often experienced the sting of exclusion from male judges (Solberg 2006). Women who might be perceived, or who identify as, feminist have been deemed unfit for the judiciary (Backhouse 2003)—typically as part of a backlash against women's appointment generally (Hunter 2006).

\section{Women Judges Making a Difference?}

It is not surprising that the under-representation of women in judicial office has led to a range of rationales for their increased representation. These rationales include equality of opportunity, representativeness, and, most recently, the need for diversity (Feenan 2008b). One of the early arguments was also that women would make a difference in judging (Abrahamson 1984). Initially, feminist proponents saw this as necessary to redress the male biases of the judiciary, but the rationale developed, particularly through the 1990s, to encompass broader approaches (whether named as 
feminist or not). Some women judges denied that they would, or should, bring a difference to judging (Cedarbaum 1993; O'Connor 1991). A greater number have said that they believe that they or other women do bring a difference, with that difference ranging widely across a range of features of judging. Most of those who have acknowledged such difference have done so, however, in terms of how their experience - as women - of discrimination has enabled them to identify with the position of others in similar positions (Wald 2005; Panel 1990). Abrahamson (1998), for instance, said that "a woman judge's special commitment comes from her personal experiences of suffering some injury or injustice from unfair treatment" and that "[a]s outsiders to the system, women judges must be committed to making a special effort to understand other outsiders - the old, the poor, the differently abled, members of racial, ethnic, religious and cultural minorities" (p. 211).

There is some data on decisional outcomes-mainly from North America-that would appear to confirm that in some cases women judges judge differently from male judges, though the data is equivocal. The following studies give a flavour of the themes. Allen and Wall (1993) concluded that women judges "act as Representatives when confronted with issues that are of immediate concern to women [and] that a larger number of [them] behave as Outsiders, while a smaller proportion manifest behavior indicative of the Different Voice role" (p. 165; cf. Martin 1993). Empathic identification with those who claim discrimination might explain data that women judges were $11 \%$ more likely to vote for the plaintiff in employment discrimination claims (Farhang and Wawro 2004). A number of studies found women judges were more likely than men to uphold employment discrimination claims (Davis et al. 1993; Kruse 2005) and on a wider range of issues (Davis 1986). A survey of lawyers and judges in Florida found that women judges were more conscious of gender inequality, observed more gender bias in legal settings and made a stronger connection between experiences with gender bias and feminist consciousness (Martin et al. 2002). Yet, there have been studies of courts which reveal no significant gender differences (Gottschall 1983; Songer et al. 1994; McCormick and Job 1993; Westergren 2004). Moreover, Walker and Barrow (1985) found no difference between men and women judges on 'women's issues' such as reproductive freedom, affirmative action, maternity rights, sexual harassment, and gender discrimination. They report that women judges were more deferential to men judges in cases involving federal regulation, and voted less often than men judges in cases involving policy affecting minorities. Studies on sentencing vary, with some surveys finding no significant differences in urban trial courts (Kritzer and Uhlman 1977; Gruhl et al. 1981), whereas a later study found that women judges impose harsher penalties for certain offences (Steffensmeier and Hebert 1999).

It has been argued that absence of difference can be explained by small samples, an effect in early studies where 'token' women were more likely to conform to dominant male behaviour, failure to account for other variables such as ideology, and inclusion of issues where gender was less salient (Peresie 2004-2005). Moreover, a number of the studies have limited value because they failed to examine how the cases came to court. Nonetheless, a number of recent studies confirm some gender effects. Women judges in the USA are more likely than men 
judges to find unconstitutional laws affecting gay Americans, an effect hypothesised as reflecting women's heightened appreciation of how gender role is related to sexual orientation (Smith 2005). Gender is more statistically significant than party of appointment in predicting case outcomes in the Ontario Court of Appeal (Stribopoulos and Yahya 2007).

Moreover, gender is reported as having a moderating effect on panel decisions. Gryski et al. (1985) found that the presence of women on US state courts as a last resort was of some predictive value in determining the outcome of sex discrimination claims. Farhang and Wawro (2004) noted that when a woman serves on a panel, the men on that panel tend to vote more liberally, and at about the same rate as women. The presence of a woman judge on three-judge federal appellate panels in cases involving sexual harassment or sex discrimination significantly increased the probability that a male judge supported the plaintiff (Peresie 2004-2005). There is similar evidence that the likelihood of a man judge ruling in favor of the plaintiff increases by $12-16 \%$ when a woman judge sits on the panel (Boyd et al. 2007). Anecdotal evidence from elsewhere corroborates such moderating influences (Hale 2006). These gender effects on panels are, perhaps, not surprising. Cameron and Cummings (2003) found that racial minority judges vote differently from racial majority (white) judges in affirmative action cases in US federal courts. They also found that the addition of a racial minority judge to an appellate panel significantly increased the probability of votes in favour of affirmative action by his or her panel colleagues. And in terms of dissenting, there is some evidence that women judges have been more willing to dissent than their male brethren (McCormick 1998; cf. Belleau and Johnson 2004, 2008).

The research on decisional outcomes is, of course, only one aspect of judging. There are reports of gender differences across a range of other aspects of judging. A number of US women judges, for instance, have adverted to slight differences from men in judicial behaviour (Tacha 1995; Beiner 2005), including humanising the courtroom (Abrahamson 1984; Turner and Breslin 2003). While little attention has been paid to women judges' working lives (Darbyshire 2006), Sharyn Roach Anleu and Kathy Mack in their article in this special issue develop our understanding of those lives through their study on gender and job satisfaction among magistrates in Australia. Roach Anleu and Mack reveal that while men and women like the nature of their work, and share high levels of satisfaction across a range of aspects of employment, women are less satisfied across a significant range of other aspects of their working lives, such as policies, administration and resources. While further research is indicated to explore the reasons for these differences, the results illuminate gendered experiences of the judiciary as occupation. The most marked difference reported is in women's dissatisfaction with control over the amount of work and over the manner of work. Women are less satisfied than men with aspects of convenience and lifestyle, including compatibility with family responsibilities, though there is more pronounced difference from men in views on hours of work. These lower levels of satisfaction may reflect women's extra 'second shift' responsibilities, including daily household tasks and care-work. Women are also, for instance, $21 \%$ less satisfied than men in their working relationships with other magistrates - which may indicate their feeling excluded from informal activities, 
information and overall workplace culture, which has been noted in other studies (Feenan 2007). The gendered differences in job satisfaction suggest the need for policy consideration of interventions that will ensure equality within the workplace.

The extra-curial work of judges needs also to be addressed. Women judges in the US have been instrumental in addressing gender stereotyping and helping create state and federal task forces to examine gender bias in courts, e.g. the Gender Bias Taskforces which confirmed extensive gender bias across the states (Resnik 1996). Haesook Kim argues in her article in this special issue that an 'avalanche' of women into the judiciary in Korea was accompanied by substantive changes in the law that advanced women's equality more broadly. Importantly, the presence of more women in the judiciary also, she notes, enhances societal attitudes towards women's equal participation generally in Korean society. Finally, a number of women judges have referred to the importance of role modeling for young women (Farrer 1997).

However, there remain a number of theoretical and normative problems with some of the 'difference' studies (Malleson 2003; Kenney 2008). The studies are often poorly theorized with reference to gender and judging, ignoring socialisation and structural variables. The assumptions about gender risk reifying sex-stereotypes that have historically harmed women. Moreover, as Erika Rackley points out in her article in this special issue, a focus on particular differences such as ethnicity, sex, and class in isolation from each other reifies oppositional divisions within understandings of difference "ignoring its multiple dimensions and the contingency of the concept itself". Starting from the perceived difference of Brenda Hale as the first female Law Lord, she seeks to re-orientate the debate as to whether women judge differently to analyse how questions about difference are framed and why such questions are asked. Rackley aims to refocus the debate onto 'difference' per se rather than seeking to determine whether women judge differently. What, she asks, might such questions reveal about understandings of the judge and judging? Rackley lays out important conceptual questions, without necessarily seeking answers, which can usefully inform future research on judging.

Some of this work is now turning to exploring feminist judging as the site of difference (see, e.g. Hunter 2008; Kenney 2008). In this special issue, Beverley Baines argues that the introduction of the concept of 'contextualism' by Justice Bertha Wilson into Canadian Supreme Court jurisprudence in one appellate case is consistent with feminist legal methodology, even if Wilson did not self-identify as feminist. She concludes that Wilson's 'contextualism' merits consideration as a new approach to feminist judging.

The insistence on difference-whether such difference is true or not-can place undue pressure on women to make a difference (Malleson 2003), though, as Hunter (2008) points out, the expectation to make a difference should lie with feminist judges. Even if there appears to be some gender effect on decisional outcomes in some gender-related cases, a number of questions remain. In what particular ways is such difference effectuated? Is it in a different approach to facts or precedents? Why gender appears to have an effect on judicial panels remains unanswered. The mere token presence of women in the judiciary-one which does not reflect their proportion (or diversity) in the wider population-is unlikely to reveal particularly nuanced gender effects (cf. Moloney Smith 1994). Critical attention needs to be paid 
to the theoretical frames that influence the 'difference' studies, and the contexts in which women judges judge. More work might also be done on pathways by which different women make it to the bench (Williams 2006), and the intersections of disadvantage, where ethnicity, class, disability and sexual orientation can intersect to create complex disadvantages (Grabham et al. 2008). These are some of the many issues that might still be explored. The articles in this special issue advance that inquiry on women and judging.

Acknowledgements This special issue was completed thanks to a grant from the School of Law, University of Ulster, and a Visiting Scholarship on the Feminism and Legal Theory Project, Emory University, April 2008. Particular thanks are due to Professor Martha A. Fineman, Professor Margaret Thornton and the journal's anonymous referees.

\section{References}

Abrahamson, Shirley S. 1984. The woman has robes: Four questions. Golden Gate Law Review 14: 489_ 503.

Abrahamson, Shirley S. 1998. Do women judges really make a difference? The American experience. In Women in law, ed. Shimon Shetreet, 195-216. London: Kluwer.

Allen, David W., and Diane E. Wall. 1993. Role orientations and women state Supreme Court justices. Judicature 77: 156-165.

Backhouse, Constance. 2003. The chilly climate for women judges: Reflections on the backlash from the Ewanchuk case. Canadian Journal of Women and Law 15: 167-193.

Bartlett, Katharine T. 1990. Feminist legal methods. Harvard Law Review 103: 829-888.

Beiner, Teresa M. 2005. Female judging. University of Toledo Law Review 36: 821-847.

Bell, John. 2006. Judiciaries within Europe: A comparative review. Cambridge: Cambridge University Press.

Belleau, Marie-Claire, and Rebecca Johnson. 2004. La dissidence judiciaire: Réflexions preliminaires sur les emotions, la raison et les passions du droit/Judicial dissent: Early reflections on emotion, reason and passion in law. In Claire L'Heureux Dubé à la Cour Suprême du Canada, 1987-2002, ed. Marie-Claire Belleau, and François Lacasse, 699-719. Québec: Wilson and Lafleur.

Belleau, Marie-Claire, and Rebecca Johnson. 2008. Judging gender: Difference and dissent at the Supreme Court of Canada. International Journal of the Legal Profession 15: 57-71.

Berns, Sandra. 1990. To speak as a judge: Difference, voice and power. Dartmouth: Ashgate.

Boyd, Christina L., Lee Epstein, and Andrew D. Martin. 2007. Untangling the causal effects of sex on judging. http://papers.ssrn.com/sol3/papers.cfm?abstract_id=1001748. Accessed 4 Sept 2008.

Brockman, Joan. 1992. "Resistance by the club" to the feminization of the legal profession. Canadian Journal of Law and Society 7(2): 47-92.

Brockman, Joan. 2001. Gender in the legal profession: Fitting or breaking the mould. Vancouver: UBC Press.

Cameron, Charles M., and Craig P. Cummings. 2003. Diversity and judicial decision-making: Evidence from affirmative action cases in the Federal Courts of Appeals, 1971-1999. http://www.yale.edu/ coic/CameronCummings.pdf. Accessed 4 Sept 2008.

Capers, I. Bennett. 2006. On Justicia, race, gender, and blindness. Michigan Journal of Race and Law 12: 203-233.

Cardinal, Monique. 2008. Women and the judiciary in Syria: Appointments process, training and career paths. International Journal of the Legal Profession 15(1\&2): 123-139.

Cedarbaum, Miriam G. 1993. Women on the federal bench. Buffalo University Law Review 44: 39-44.

Cowan, Ruth B. 2006. Women's representation on the courts in the Republic of South Africa. University of Maryland Journal of Race, Religion, Gender and Class 6: 291-317.

Curtis, Dennis E., and Judith Resnik. 1987. Images of justice. Yale Law Journal 96: 1727-1772.

Darbyshire, Penny. 2006. Cameos from the world of district judges. Journal of Criminal Law 70: 443457. 
Davis, Sue. 1986. President Carter's selection reforms and judicial policymaking: A voting analysis of the United States Courts of Appeals. American Politics Quarterly 14: 328-344.

Davis, Sue, Susan Haire, and Donald Songer. 1993. Voting behavior and gender on the United States Courts of Appeals. Judicature 77: 127-133.

Epstein, Cynthia Fuchs. 1998. Reaching for the top: 'The glass ceiling' and women in the law. In Women in law, ed. Shimon Shetreet, 105-130. Kluwer: London.

Farhang, Sean, and Gregory Wawro. 2004. Institutional dynamics on the U.S. Court of Appeals: Minority representation under panel decision-making. Journal of Law, Economics and Organization 20(2): 299-330.

Farrer, Nancy L. 1997. Of ivory columns and glass ceilings: The impact of the Supreme Court of the United States on the practice of women attorneys in law firms. St. Mary's Law Journal 28: 529-571.

Feenan, Dermot. 2005. Applications by women for silk and judicial office in Northern Ireland. A Report for the Commissioner for Judicial Appointments for Northern Ireland. Jordanstown: School of Law, University of Ulster.

Feenan, Dermot. 2007. Understanding disadvantage partly through an epistemology of ignorance. Social and Legal Studies 16: 509-531.

Feenan, Dermot. 2008a. Judicial appointments in Ireland in comparative perspective. Judicial Studies Institute Journal 1: 37-66.

Feenan, Dermot. 2008b. Women judges: Gendering judging, justifying diversity. Journal of Law \& Society 35: 490-519.

Formisano, Maritza, and Valentine M. Moghadam. 2005. Women in the judiciary in Latin America: An overview of progress and gaps (SHS Papers in Women's Studies/Gender Research, No. 5). Paris: UNESCO.

Genn, Hazel. 2008. The attractiveness of senior judicial appointment to highly qualified practitioners. Report to the Judicial Executive Board. London: Directorate of Judicial Offices for England and Wales.

Gottschall, Jon. 1983. Carter's judicial appointments: The influence of affirmative action and merit selection on voting on the U.S. Courts of Appeals. Judicature 67: 165-173.

Grabham, Emily, Davina Cooper, Jane Krishnadas, and Didi Herman (eds.). 2008. Intersectionality and beyond: Law, power and the politics of location. London: Routledge.

Graycar, Reg. 1995. The gender of judgments: An introduction. In Public and private: Feminist legal debates, ed. Margaret Thornton, 262-282. Oxford: Oxford University Press.

Gruhl, John, Cassia Spohn, and Susan Welch. 1981. Women as policy makers: The case of trial judges. American Journal of Political Science 25: 308-322.

Gryski, Gerard S., Eleanor C. Main, and William C. Dixon. 1985. Models of state high court decisionmaking in sex discrimination cases. Journal of Politics 48(1): 143-155.

Hale, Brenda. 2006. The appointment and removal of judges: Independence and diversity. Speech to the International Association of Women Judges, 8th biennial conference, 3-7 May, Sydney, Australia.

Harris, Angela P. 1990. Race and essentialism in feminist legal theory. Stanford Law Review 42: 585616.

Hunter, Rosemary. 2006. The high price of success: The backlash against women judges in Australia. In Calling for change: Women, law and the legal profession, ed. Sheila McIntyre, and Elizabeth Sheehy, 281-301. Ottawa: University of Ottawa Press.

Hunter, Rosemary. 2008. Can feminist judges make a difference? International Journal of the Legal Profession 15: 7-36.

Kay, Fiona M. 1997. Flight from law: A competing risks model of departures from law firms. Law and Society Review 31: 301-335.

Kenney, Sally J. 2008. Thinking about gender and judging. International Journal of the Legal Profession 15: 87-110.

Kritzer, Herbert M., and Thomas M. Uhlman. 1977. Sisterhood in the courtroom: Sex of judge and defendant in criminal case disposition. Social Science Quarterly 14: 77-88.

Kruse, Brenda. 2005. Women of the highest court: Does gender bias or personal life experiences influence their opinions? University of Toledo Law Review 36: 995-1022.

Malleson, Kate. 2003. Justifying gender equality on the bench: Why difference won't do. Feminist Legal Studies 11: 1-24.

Malleson, Kate, and Peter H. Russell (eds.). 2006. Appointing judges in an age of judicial power. Toronto: University of Toronto Press.

Martin, Elaine. 1993. The representative role of women judges. Judicature 77: 166-172. 
Martin, Patricia Yancey, John T. Reynolds, and Shelley Keith. 2002. Gender bias and feminist consciousness among judges and attorneys: A standpoint theory. Signs 27: 665-701.

McCormick, Peter. 1998. Birds of a feather: Alliances and influences on the Lamer court 1990-1997. Osgoode Hall Law Journal 36: 339-368.

McCormick, Peter, and Twyla Job. 1993. Do women judges make a difference? An analysis of appeal court data. Canadian Journal of Law and Society 8(1): 135-148.

Moloney Smith, Susan. 1994. Diversifying the judiciary: The influence of gender and race on judging. University of Richmond Law Review 28: 179-204.

NISRA (Northern Ireland Statistics and Research Agency). 2008. The judiciary in Northern Ireland: 2008 equity monitoring report. Belfast: Northern Ireland Statistics and Research Agency.

O'Connor, Sandra Day. 1991. Portia's progress. New York University Law Review 66: 1546-1558.

Panel. 1990. Different voices, different choices? The impact of more women lawyers and judges on the justice system. Judicature 74: 138-146. (An edited transcript of the panel at the AJS Annual Meeting, August 4, 1990).

Peresie, Jennifer L. 2004-2005. Female judges matter: Gender and collegial decisionmaking in the federal appellate courts. Yale Law Journal 114: 1759-1790.

Rackley, Erika. 2002. Representation of the (woman) judge: Hercules, the little mermaid, and the vain and naked emperor. Legal Studies 22: 602-624.

Resnik, Judith. 1996. Asking about gender in courts. Signs 21: 952-990.

Schneider, Elizabeth M. 2007. The dangers of summary judgment: Gender and federal civil litigation. Rutgers Law Review 59: 705-777.

Schultz, Ulrike, and Gisela Shaw (eds.). 2003. Women in the world's legal professions. Oxford: Hart Publishing.

Smith, Fred O. 2005. Gendered justice: Do male and female judges rule differently on questions of gay rights? Stanford Law Review 57: 2087-2134.

Solberg, Rorie Spill. 2006. Court size and diversity on the bench: The ninth circuit and its sisters. Arizona Law Review 48: 247-266.

Songer, Donald R., Sue Davis, and Susan Haire. 1994. A reappraisal of diversification in the federal courts: Gender effects in the Courts of Appeals. Journal of Politics 56: 425-439.

Steffensmeier, Darrell, and Chris Hebert. 1999. Women and men policymakers: Does the judge's gender affect sentencing of criminal defendants? Social Forces 77: 1163-1196.

Stribopoulos, James, and Moin A. Yahya. 2007. Does a judge's party of appointment or gender matter to case outcomes?: An empirical study of the Court of Appeal for Ontario. Osgoode Hall Law Journal 45: 315-363.

Tacha, Deanell. 1995. "W" Stories: Women in leadership positions in the judiciary. West Virginia Law Review 97: 683-701.

Thornton, Margaret. 1996. Dissonance and distrust: Women in the legal profession. Melbourne: Oxford University Press.

Thornton, Margaret. 2007. "Otherness" on the bench: How merit is gendered. Sydney Law Review 29: 391-413.

Thornton, Margaret, and Joanne Bagust. 2007. The gender trap: Flexible work in corporate legal practice. Osgoode Hall Law Journal 45: 773-811.

Turner, Robert C., and Beau Breslin. 2003. The impact of female state chief justices on the administration of state judiciaries. Paper presented at the annual meeting for the Midwest Political Science Association, 3-6 April, Chicago, IL.

Wald, Patricia. 2005. Six not-so-easy pieces: One woman judge's journey to the bench and beyond. University of Toledo Law Review 36: 979-993.

Walker, Thomas G., and Deborah J. Barrow. 1985. The diversification of the federal bench: Policy and process ramifications. Journal of Politics 47: 596-617.

Westergren, Sarah. 2004. Gender effects in the Court of Appeals revisited: The data since 1994. Georgetown Law Journal 92: 689-708.

Williams, Margaret. 2006. In a different path: The process of becoming a judge for women and men. Judicature 90: 104-113. 